\title{
Records of the Horned Toad in Saskatchewan
}

By ROBERT W. NERO, Saskatchewan Museum of Natural History

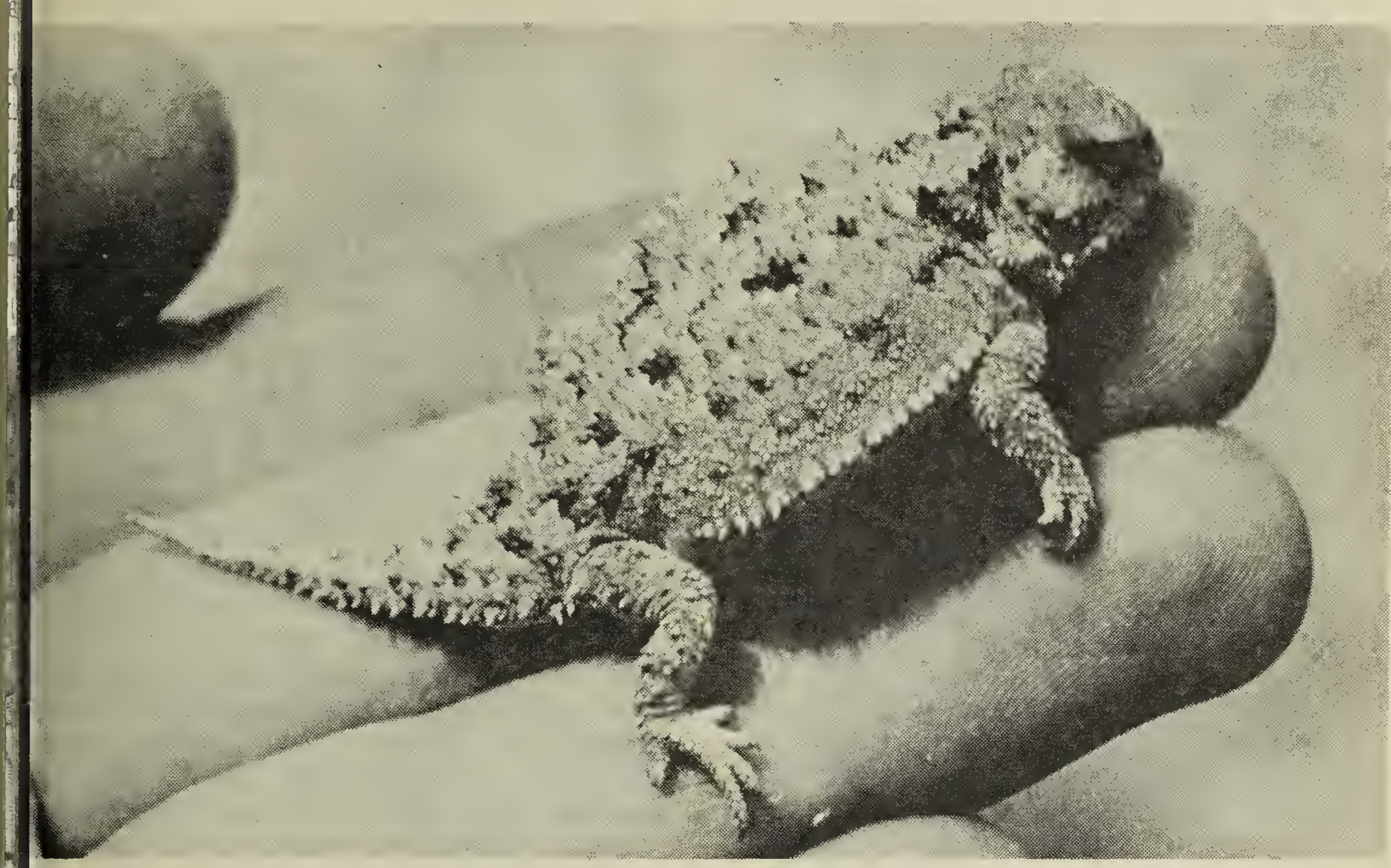

Photo by F. W. Lahrman

A Horned Toad, or more properly Horned Lizard, recently received rom Mrs. Don Gillespie of Rosefield, ask., provides the second official ecord of a lizard in the province. previously unreported specimen of Horned Toad in the National Iuseum was collected at Gergovia n August 22, 1931. The present recrd is from the same area. It vas captured on June 1,1957 lear Rosefield (23, 1, 11, W23rd). Mrs. Gillespie wrote: "My siser and I went for a walk on une 1 and I just picked him ip and put him in my pocket. They are found anywhere in the badands where there are outcroppings f blue shale. I have seen a lot of hem but never more than one at a ime in one place. You see them nostly in dry years."

This information should help us ind other specimens and thus extend ur knowledge of the distribution of his interesting animal. We look orward to further reports from natiralists in that section of the proince. The semi-desert conditions which are found in far southwestern askatchewan have long been presimed to provide conditions suitable o the occurrence of the Horned izard. Dr. E. B. S. Logier has ointed out that the distribution range drawn by H. M. Smith (1946. Handbook of Lizards. Comstock, New York) includes the extreme southwestern corner of Saskatchewan (pers. corres.). Logier and Toner state that it occurs in southwestern Alberta north to about 50 degrees latitude (1955. Check-list of the Amphibians of Reptiles of Canada and Alaska. Contrib. Royal Ont. Mus. Zool. Pal., No. 41). According to the same authors our lizard should be the Eastern Short-horned Toad (Phrynosoma douglassi brevirostre Girard). The identification of our specimen as such has been confirmed by Dr. Sherman Bleakney who also sent the information on the National Museum specimen.

As shown by the photo our specimen is small, being a little over two and one half inches in total length. It was alive when received and was brownish-gray above, yellowishwhite below. It was quite sluggish during the period we had it under observation, even when being photographed outside in the sun. However, as pointed out by several authors, this is a creature which likes very hot days, when it becomes quick and active. Its food, like most lizards consists mainly of insects. Unlike many lizards, the young of this group are born alive. Horned lizards are 
generally supposed to be docile and have not been known to bite. According to G. C. Carl, however, when irritated they may open the mouth, hiss or inflate the body (1951. Reptiles of British Columbia).

Under extreme irritation they may even suddenly eject a thin stream of blood from the corner of an eye! This astounding feat has been well authenticated, and it amuses me to wonder whether it might have been the origin of the expression "mud in your eye"!

\section{"Taming the Shrew"}

By RICHARD W. FYFE, Saskatchewan Museum of Natural History

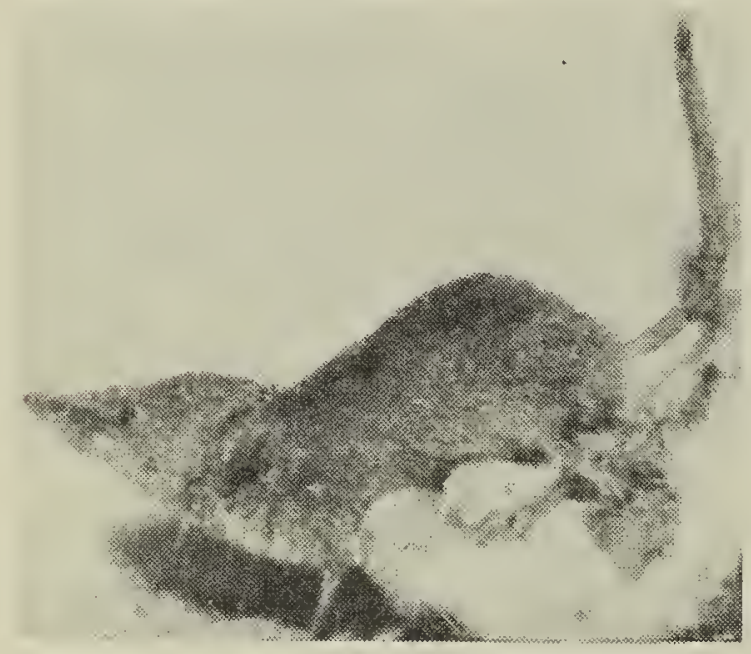

Common Shrew, natural size

The cover photo and those on this page are of a Common Shrew recently donated to the museum by some junior naturalists in Regina. The live animal is pictured here behind glass and feeding on a White-footed Mouse.

The Common Shrew is usually found in areas of brush or on the prairie near streams or other water areas. Seldom seen because of their small size, they are more common than we realize. Although they have a total length of from $31 / 2$ to 4 inches and a weight about that of a penny (3.6 gm.), they are noted for their fearlessness and will occasionally attack and kill mice much larger than themselves. However, the main die of most shrews is insects which are more easily obtained. Having a vers high metabolic rate with a heart bea of 1,600 beats a minute, they requir a tremendous amount of food and art reported by some authors to eat ui to three times their weight in foor per day. They are admirably equip. ped to do so, because they have piercing teeth and because they car poison their prey with venom simila: to that of a cobra. Although th Common Shrew is not considere very poisonous, one other membe of the shrew family, the Short-taile Shrew, can inject enough poison int humans to cause considerable paij for one or two weeks.

The Pygmy Shrew, which is th world's smallest mammal, is ofte: confused with the Common Shrev shown here. This is very understand able as they are similar in appear ance. Although the Pygmy Shrew: slightly smaller, it can only be dis tinguished by an examination of it tooth pattern. However, the Com mon Shrew is the one most ofte found in Saskatchewan. Question able specimans should be sent to th museum for identification.

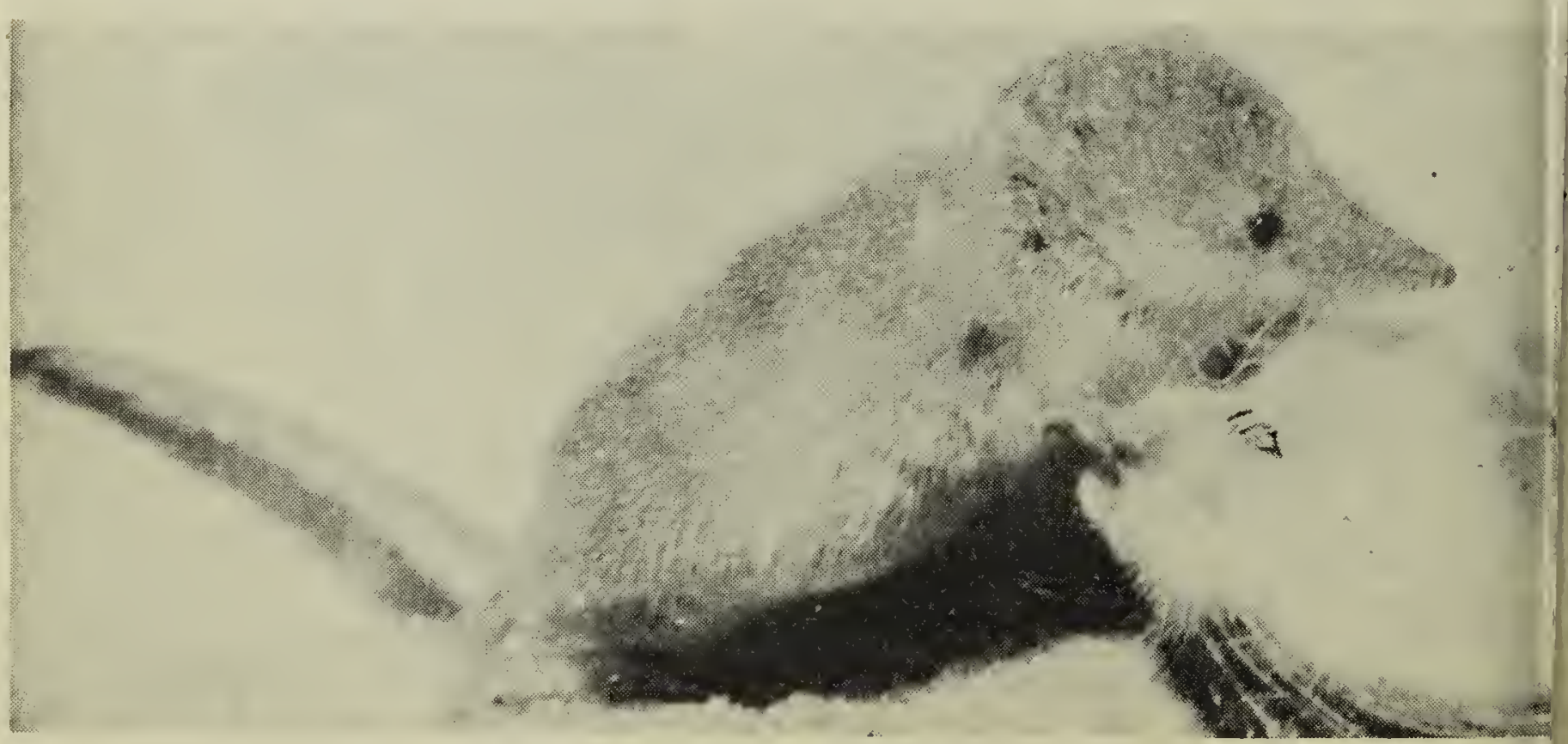

